Syntax Literate: Jurnal Ilmiah Indonesia p-ISSN: 2541-0849 e-ISSN: 2548-1398

Vol. 6, No. 12, Desember 2021

\title{
PENGARUH KEPUASAN NASABAH, EKUITAS MEREK, CITRA PERUSAHAAN, DAN KEPUASAN PELANGGAN TERHADAP LOYALITAS PELANGGAN
}

\author{
Alan Andhika \\ Fakultas Ekonomi dan Bisnis, Universitas Pelita Harapan (UPH) Jakarta, Indonesia \\ Email: karamoyalan@gmail.com
}

\begin{abstract}
Abstrak
Penelitian ini bertujuan untuk menganalisis bukti empiris pengaruh kualitas pelayanan, ekuitas merek, citra perusahaan dan kepuasan pelanggan terhadap loyalitas pelanggan pada BSI Mobile, sebuah aplikasi digital banking milik PT Bank Syariah Indonesia Tbk. Sampel dalam penelitian ini sebanyak 191 pengguna BSI Mobile, teknik pengambilan sampel probability sampling, yakni teknik pengambil sampel yang memberikan peluang yang sama bagi setiap anggota populasi untuk dipilih menjadi anggota sampel. Analisis data yang digunakan adalah Structural Equation Modelin (SEM). Hasil ini menunjukan bahwa dengan dengan meningkatkan kualitas pelayanan, ekuitas merek, citra perusahaan dan kepuasan pelanggan memiliki pengaruh yang positif terhadap loyalitas pelanggan. Ekuitas merek, citra perusahaan dan kepuasan nasabah memiliki pengaruh yang positif dan signifikan terhadap loyalitas nasabah, dimana membuktikan bahwa dengan peningkatan ekuitas merek, citra perusahaan yang baik dan kepuasan nasabah yang positif akan menciptakan pelanggan yang loyal dan akan terus menggunakan BSI Mobile. Kualitas pelayanan memiliki pengaruh yang positif namun tidak signifikan terhadap loyalitas nasabah, dimana membuktikan bahwa hanya sebuah kualitas pelayanan yang baik saja tidak cukup untuk membuat pelanggan loyal dan akan terus menggunakan BSI Mobile milik PT Bank Syariah Indonesia Tbk.
\end{abstract}

Kata Kunci: kualitas pelayanan; ekuitas merek; citra perusahaan; kepuasan pelanggan; loyalitas pelanggan.

\section{Abstract}

This study aims to analyze empirical evidence of the effect of service quality, brand equity, corporate image and customer satisfaction on customer loyalty at BSI Mobile, a digital banking application owned by PT Bank Syariah Indonesia Tbk. The sample in this study consisted of 191 BSI Mobile users. The sampling technique was probability sampling, which is a sampling technique that provides equal opportunities for each member of the population to be selected as a sample member. The data analysis used was Structural Equation Modeling (SEM). These results indicate that improving service quality, brand equity, corporate image and customer satisfaction has a positive influence on customer loyalty. Brand equity, company image and customer satisfaction have a positive and significant impact on

$\begin{array}{ll}\text { How to cite: } & \text { Andhika. A (2021) Pengaruh Kepuasan Nasabah, Ekuitas Merek, Citra Perusahaan, dan Kepuasan Pelanggan } \\ & \text { Terhadap Loyalitas Pelanggan. Syntax Literate: Jurnal Ilmiah Indonesia, 6(12) http://dx.doi.org/10.36418/ } \\ & \text { Syntax-Literate.v6i12.5035 } \\ \text { E-ISSN: } & \text { 2548-1398 } \\ \text { Published by: } & \text { Ridwan Institute }\end{array}$


customer loyalty, which proves that with an increase in brand equity, good corporate image and positive customer satisfaction will create loyal customers and will continue to use BSI Mobile. Service quality has a positive but insignificant influence on customer loyalty, which proves that just a good service quality is not enough to make customers loyal and will continue to use BSI Mobile owned by PT Bank Syariah Indonesia Tbk.

Keywords: service quality; brand equity; corporate image; customer satisfaction; and customer loyalty.

Received: 2021-11-20; Accepted: 2021-12-05; Published: 2021-12-20

\section{Pendahuluan}

Pada zaman ini kita telah memasuki yang disebut sebagai era digital, dimana ada pada era yang membuat kehidupan sehari hari menjadi lebih efisien, efektif dan juga praktis didukung oleh adanya kemajuan yang pesat khususnya di bidang digital dan teknologi. Kemajuan teknologi di dukung dengan akses internet, dan akan semakin berkembang bersamaan dengan perkembangan zaman. Dengan adanya kemajuan digital dan teknologi yang menimbulkan sebuah ekspansi yang praktis dan juga inovatif untuk layanan keuangan. Perkembangan teknologi ini merupakan sebuah inovasi yang bukan hanya merubah sistem keuangan itu sendiri namun juga perilaku dan ekspektasi manusia dalam mendapatkan berbagai informasi dan fitur layanan elektronik, hal ini yang disebut sebagai "Financial Technology" atau "Fintech".

Digitalisasi menimbulkan sebuah trend baru dimana harus dilakukan penyesuaian terhadap industri-industri agar dapat mengukuti perkembangan zaman yang terus berkembang. Hal ini tentunya terjadi di industri perbankan. dimana pada era ini telah terdapat banyak perusahaan perbankan maupun institusi di bidang keuangan di Indonesia yang menyediakan layanan digital banking, seperti internet banking ataupun mobile banking. Di era digital pada saat ini perkembangan teknologi seperti contohnya digital banking pada industri perbankan harus semakin gencar dilakukan. Tentunya hal ini harus diadakan demi mendapatkan pelanggan atau nasabah baru, khususnya pada generasi muda atau yang disebut juga milenial yang sangat peduli dengan adanya perkembangan teknologi atau yang disebut sebagai tech savvy.

Layanan perbankan digital (digital banking) ditujukan untuk meningkatakan mutu pelayanan sebuah bank terhadap nasabahnya dan juga efisiensi kegiatan yang bersifat operasional. Dimana pada zaman ini sebuah bank perlu mengembangkan strategi yang mengarah kepada pelayanan perbankan digital.

Jumlah pemakai internet pada lima tahun terkahir tercatat selalu mengalami peningkatan. Akses Internet dunia telah berkembang dengan sangat pesatnya sehingga masyarakat dapat mengakses hampir setiap saat untuk melakukan segalanya mulai dari memeriksa laporan bank hingga belanja, serta mencari informasi dan menikmati hiburan. Sebagaimana dijelaskan pada tabel 1 di tahun 2016 terdapat 3,42 milyar pemakai internet, sedangkan pada tahun 2020 ada 4,54 milyar pemakai internet dunia. 
Terdapat kenaikan sebesar 32,75\% terhadap pemakai internet dunia dari tahun 2016 hinggan tahun 2020 .

Tabel 1

Jumlah Pemakai Koneksi Internet di Dunia dalam Milyar

\begin{tabular}{cc}
\hline Pemakai Koneksi Internet di Dunia & Jumlah Pemakai dalam Milyar \\
\hline 2016 & 3,42 \\
\hline 2017 & 3,77 \\
\hline 2018 & 4,02 \\
\hline 2019 & 4,39 \\
\hline 2020 & 4,54 \\
\hline
\end{tabular}

(Sumber: www.statista.com)

Peningkatan pemakaian internet tentunya juga terjadi di Indonesia. Berdasarkan data pada Badan Pusat Statistik Indonesia bahwa distribusi pemakaian internet pada Indonesia yakni 56,4 \% dari Pulau Jawa, 22,1\% dari Pulau Sumatera, 7\% dari Pulau Sulawesi, 6,3\% dari Pulau Kalimantan, 5,2\% dari Bali \& Nusa Tenggara dan 3\% pemakai dari Maluku \& Papua. Sebagaimana dijelaskan pada tabel 2 mengenai pemakai internet di tahun 2016 terdapat 132,7 juta pemakai internet dan pada tahun 2020 angka ini meningkat 50,1\% menjadi 199,16 juta pemakai internet di negara Indonesia.

\section{Tabel 2}

Jumlah Pemakai Koneksi Internet di Indonesia dalam Jutaan Pemakai Koneksi Internet di Indonesia Jumlah Pemakai dalam Jutaan

\begin{tabular}{ll}
\hline 2016 & 132,7 \\
\hline 2017 & 143,26 \\
\hline 2018 & 171,17 \\
\hline 2019 & 184,94 \\
\hline 2020 & 199,16 \\
\hline
\end{tabular}

(Sumber: www.statista.com)

Pemanfaatan teknologi informasi di Indonesia mengalami pertumbuhan yang sangat pesat, diikuti dengan pertumbuhan jumlah pemakai telepon pintar (smartphone). Sebagaiman dijelaskan pada Tabel 3 bahwa terdapat 110,02 juta pemakai di tahun 2016, namun terdapat 189,63 juta pemakai di tahun 2020, dimana ada 72,36\% kenaikan pada pemakai koneksi internet pada telepon genggam/telepon pintar (smartphone) di Indonesia pada tahun 2016 hingga tahun 2020. 
Tabel 3

Jumlah Pemakai Koneksi Internet pada Telepon Genggam di Indonesia dalam jutaan

\begin{tabular}{cc}
\hline $\begin{array}{c}\text { Pemakai Koneksi Internet pada Telepon } \\
\text { Genggam di Indonesia }\end{array}$ & $\begin{array}{c}\text { Jumlah Pemakai dalam } \\
\text { Jutaan }\end{array}$ \\
\hline 2016 & 110,02 \\
\hline 2017 & 123,07 \\
\hline 2018 & 151,34 \\
\hline 2019 & 167,38 \\
\hline 2020 & 189,63 \\
\hline
\end{tabular}

(Sumber: www.statista.com)

Perkembangan di bidang teknologi informasi berdampak pada iklim usaha yang semakin kompetitif. Akibatnya, volume kegiatan ekonomi digital semakin masif. Otoritas Jasa Keuangan (OJK) mengungkapkan e-banking memberikan kemudahan nasabah melalui pelayanan operasional yang beragam. Pada (Keuangan, 2015) dijelaskan bahwa layanan e-banking yang dimaksud termasuk jenis delivery channel umum contohnya ATM yang dimana hampir setiap bank memilikinya. Selain itu juga terdapat delivery channel lainnya seperti: SMS banking, phone banking, mobile banking dan juga internet banking.

Pada tabel 4 dijelaskan bahwa terdapat 13,6 juta pemakai di tahun 2012, terdapat 50,4 juta pemakai di tahun 2016 dan pada tahun 2020 terdapat 88,2 juta pemakai EBanking di Indonesia. Hal ini terdapat kenaikan 548,53\% pada pemakai E-Banking di negara Indonesia di tahun 2012 hingga tahun 2020.

\section{Tabel 4}

Jumlah Pemakai E-Banking di Indonesia dalam Jutaan Pemakai E-Banking di Indonesia Jumlah Pemakai dalam Jutaan

$\begin{array}{ll}\mathbf{2 0 1 2} & 13,6 \\ \mathbf{2 0 1 6} & 50,4 \\ \mathbf{2 0 2 0} & 88,2\end{array}$

Sumber: OJK (2015) \& (Limbong et al., 2020)

Pada Tabel 5 dijelaskan bahwa terdapat 150,8 juta transaksi pada tahun 2012, terdapat 405,5 juta transaksi pada tahun 2016 dan pada tahun 2020 terdapat 513,7 juta transaksi E-Banking di Indonesia. Hal ini terdapat kenaikan 240,65\% yang signifikan pada transaksi E-Banking di Indonesia pada tahun 2012 hingga tahun 2020.

Tabel 5

Jumlah Frekuensi Transaksi E-Banking di Indonesia dalam Jutaan Frekuensi Transaksi $E$-Banking di Indonesia Jumlah Frekuensi dalam Jutaan

$\begin{array}{ll}\mathbf{2 0 1 2} & 150,8 \\ \mathbf{2 0 1 6} & 405,5 \\ \mathbf{2 0 2 0} & 513,7\end{array}$

Sumber: OJK (2015) \& OJK (2020) 
Dalam hal ini terjadi perpindahan perilaku pelanggan atau customer switching behavior. Fenomena ini adalah sebuah situasi dimana pelanggan sudah memulai untuk meninggalkan kebiasaan lama yaitusebuah produk maupun layanan awal yang digunakan dan menggantinya menjadi sebuah produk maupun layanan yang baru. Sebagaimana dijelaskan oleh (Gerrard \& Cunningham, 2004) dimana terdapat tiga faktor yang dapat mempengaruhi fenomena ini yaitu: kegagalan layanan, harga dan ketidaknyamanan. Dalam penelitian ini juga disebutkan bahwa faktor yang paling berpengaruh dalam peralihan perilaku pelanggan adalah kegagalan layanan.

PT Bank Syariah Indonesia Tbk resmi diluncurkan oleh Presiden Indonesia pada tanggal 1 Februari 2021 gabungan atau merger dari ketiga bank Syariah Badan Usaha Milik Negara (BUMN) diantaranya PT Bank BRIsyariah Tbk PT. Bank Syariah Mandiri dan PT Bank BNI Syariah. PT Bank Syariah Indonesia memiliki visi yaitu adalah menjadi 10 Bank Syariah terbesar di dunia berdasarkan kapilalisasi pasar secara global dalam waktu 5 tahun ke depan, dan integrasi secara keseluruhan di prediksi akan selesai pada bulan Oktober 2021.

Dalam masa roll-out yang akan dilakukan oleh PT Bank Syariah Indonesia Tbk akan terjadi sebuah tugas baru dimana kesadaran merek Brand Awareness terhadap bank baru ini harus dimulai lagi dari awal. Tugas terbesar PT Bank Syariah Indonesia Tbk., saat ini adalah merubah kebiasaan nasabah untuk meninggalkan kebiasaan menggunakan digital banking dari bank sebelumnya dan menggunakan BSI mobile atau aplikasi digital banking yang dimiliki oleh PT Bank Syariah Indonesia Tbk.

Melihat hasil penjelasan di atas, kita bisa mendapatkan latar masalahnya yaitu: (1) Kehadiran fintech dan digitalisasi dimana membuat perusahaan khususnya di bidang usaha perbankan harus melakukan penyesuaian dengan digital banking. (2) Terjadinya perpindahan perilaku pelanggan atau customer switching behavior dari perbankan konvensional ke perbankan digital. (3) Penggabungan atau merger 3 bank syariah yaitu: BRIsyariah, Bank Mandiri Syariah, dan BNI Syariah, dan membuat bank baru yang belum memiliki Ekuitas Merek yang kuat.

\section{Metode Penelitian}

1. Obyek Penelitian

Pada penelitian ini yang menjadi obyek pada penelitian adalah variabelvariabel yang menjadi bagian dari model pada penelitian ini yaitu: Kualitas Pelayanan, ekuitas merek, citra perusahaan, kepuasan pelanggan dan loyalitas pelanggan pada PT Bank Syariah Indonesia Tbk.

2. Unit Analisis

Menurut (Arikunto, 2016) unit analisis adalah satuan-satuan yang diteliti yang dapat berupa individu, kelompok, benda atau suatu latar. Dalam hal ini adalah nasabah PT Bank Syariah Indonesia Tbk di Indonesia, yang terbagi menjadi empat kelompok yaitu;

a. Mantan nasabah BRIsyariah

b. Mantan nasabah BNI Syariah 
c. Mantan nasabah Bank Mandiri Syariah

d. Nasabah baru Bank Syariah Indonesia Tbk.

3. Waktu dan Lokasi Penelitian

Waktu Penelitian ini dimulai pada 30 Maret 2021 hingga 9 April 2021. Lokasi Penelitian Penelitian ini di lakukan di tiga cabang milik Bank Syariah Indonesia Tbk yaitu:

a. PT Bank Syariah Indonesia KC Jakarta Barat (sebelumnya BNI Syariah) yang beralamatkan Jl Arteri Kelapa 2 No 40A RT 013 RW 001 Kebun Jeruk, Jakarta Barat.

b. PT Bank Syariah Indonesia KC Tangerang BSD City (sebelumnya BRIsyariah) yang beralamatkan di Ruko Tol Boulevard Blok C no 20-21 Jl Pahlawan Seribu, Kel Rawa Buntu, Kec Serpong, Kota Tangerang Selatan.

c. PT Bank Syariah Indonesia KC Hasanudin (sebelumnya Bank Syariah Mandiri) yang beralamatkan di Jl Sultan Hasanudin No 57 Melawai Kebayoran Baru, Jakarta Selatan

Lokasi ini diambil karena penulis ingin mendapatkan data dari pihak pertama atau nasabah PT Bank Syariah Indonesia Tbk, dimana setiap nasabah dengan bank legacy yang berbeda akan memiliki pendapat yang berbeda perihal aplikasi BSI Mobile. Selain itu peneliti juga ingin berwawancara langsung dengan kepala cabang dan juga nasabah PT Bank Syariah Indonesia Tbk.

Penelitian ini juga dilakukan secara online melalui penyebaran google form yang ke dalam grup online seperti facebook dan juga whatsapp, dimana secara spesifik disebarkan melalui komunitas komunitas pengguna bank Syariah di Indonesia.

4. Tipe Penelitian

Jenis penelitian yang dilakukan dalam penelitian ini adalah penelitian lapangan dengan pendekatan kuantitatif yaitu, jenis penelitian yang bertujuan untuk mengetahui hubungan sebab akibat atau pengaruh Kualitas Pelayanan (X1). Ekuitas Merek (X2) Citra Perusahaan (X3) Kepuasaan Pelanggan (X4) terhadap Loyalitas Pelanggan (Y).

5. Operasionalisasi Variabel Penelitian

\section{Tabel 6}

Operasionalisasi Variabel Penelitian

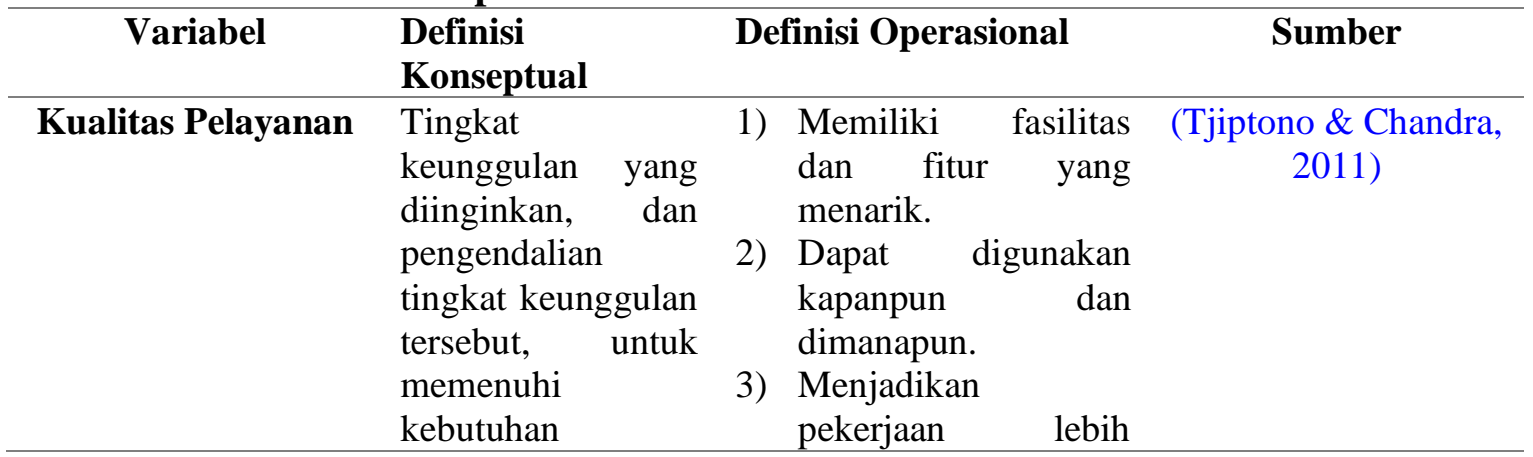




\begin{tabular}{|c|c|c|c|c|}
\hline & pelanggan & 4) & $\begin{array}{ll}\text { mudah } & \text { karena } \\
\text { kecepatan akses. } \\
\text { Dijamin kerahasiaan } \\
\text { dan kemanannya. } \\
\text { Dapat menjamin } \\
\text { setiap } & \text { kebutuhan } \\
\text { nasabah. } & \end{array}$ & \\
\hline Ekuitas Merek & $\begin{array}{lr}\text { Nilai } & \text { yang } \\
\text { ditentukan oleh } \\
\text { konsumen pada } \\
\text { merek melampaui } \\
\text { fitur atau atribut } \\
\text { fungsional produk. }\end{array}$ & $\begin{array}{l}\text { 1) } \\
\text { 2) }\end{array}$ & $\begin{array}{l}\text { Pengetahuan dasar } \\
\text { mengenai produk. } \\
\text { Variasi dan mutu } \\
\text { mempengaruhi } \\
\text { konsumen dalam } \\
\text { menggunakan } \\
\text { produk. } \\
\text { Produk yang } \\
\text { digunakan lebih baik } \\
\text { dari produk lainnya. }\end{array}$ & $\begin{array}{c}\text { (Supranto \& } \\
\text { Limiakrisna, 2011) }\end{array}$ \\
\hline Citra Perusahaan & 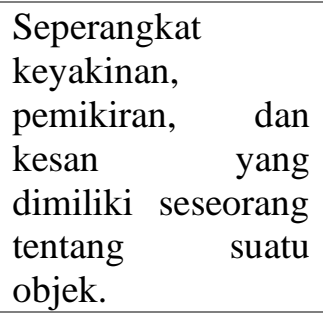 & $\begin{array}{l}\text { 2) } \\
\text { 3) }\end{array}$ & $\begin{array}{l}\text { Kemudahan } \\
\text { penggunaan produk. } \\
\text { Produk yang dapat } \\
\text { diandalkan. } \\
\text { Keyakinan yang } \\
\text { tinggi dalam } \\
\text { penggunaan produk. }\end{array}$ & $\begin{array}{l}\text { (Kotler \& Keller, } \\
\text { 2016) }\end{array}$ \\
\hline $\begin{array}{l}\text { Kepuasan } \\
\text { Pelanggan }\end{array}$ & $\begin{array}{lr}\text { Konsumen } & \text { merasa } \\
\text { senang atau } \\
\text { kecewa dengan } \\
\text { membandingkan } \\
\text { kinerja produk } \\
\text { yang dirasakan } \\
\text { dengan harapan. }\end{array}$ & 2) & 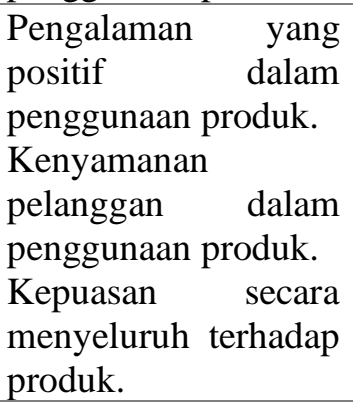 & $\begin{array}{l}\text { (Kotler \& Keller, } \\
\text { 2016) }\end{array}$ \\
\hline Loyalitas Pelanggan & $\begin{array}{l}\text { Bahkan dalam } \\
\text { situasi yang dapat } \\
\text { memengaruhi } \\
\text { perilaku dan upaya } \\
\text { pemasaran yang } \\
\text { dapat } \\
\text { memengaruhi } \\
\text { perubahan } \\
\text { perilaku, ada } \\
\text { komitmen yang } \\
\text { tinggi untuk } \\
\text { membeli kembali } \\
\text { produk yang } \\
\text { diinginkan di masa } \\
\text { mendatang. }\end{array}$ & 2) & $\begin{array}{l}\text { Komitmen pelanggan } \\
\text { untuk terus } \\
\text { menggunakan } \\
\text { produk. } \\
\text { Komitmen pelanggan } \\
\text { untuk lebih } \\
\text { menggunakan suatu } \\
\text { produk dibandingkan } \\
\text { produk lainnya. } \\
\text { Komitmen pelanggan } \\
\text { untuk mereferensikan } \\
\text { sebuah produk ke } \\
\text { pelanggan lainnya. }\end{array}$ & $\begin{array}{l}\text { (Kotler \& Keller, } \\
\text { 2016) }\end{array}$ \\
\hline
\end{tabular}


6. Populasi dan sampel

Untuk dapat melakukan analisa kuantitatif, pada penelitian ini perlu dilakukan pemahaman terhadap populasi target responden. Selain itu juga diperlukan penentuan jumlah sampel yang diperlukan terhadap penelitian ini.

a. Populasi

Dalam penelitian ini populasi yang dimaksud adalah seluruh nasabah PT Bank Syariah Indonesia yang telah menggunakan aplikasi BSI Mobile.

b. Sampel

Sampel dalam penelitian ini adalah 191 responden dari nasabah Bank Syariah Indonesia yang menggunakan aplikasi BSI Mobile.

c. Metode Penarikan Sampel

Metode penarikan sampel dalam penelitian ini digunakan teknik convenience sampling yang mendasar pada kemudahan dalam melakukan penarikan sample. Peneliti akan menyebarkan kuesioner secara langsung dan juga dengan menitipkan fisik kuesioner kepada pihak pihak dalam internal PT Bank Syariah Indonesia Tbk seperti kepala cabang dan staff divisi digital banking yang berhubungan langsung dengan target responden.

7. Metode Pengumpulan Data

Penelitian yang dilakukan dengan teknik kuantitatif ini, diperlukan setidaknya empat cara pengumpulan data yaitu kuesioner, wawancara, pengamatan, dan analisis dokumen. Untuk data kuesioner, peneliti akan membagikan kepada 191 orang responden untuk mengisi pernyataan yang berkaitan dengan indikator dari variabel variabel yang digunakan dalam penelitian ini.

Kuesioner Merupakan metode pengumpulan data primer berupa pernyataanpertanyaan tertutup secara tertulis kepada responden (nasabah) dengan pilihan 5 pilihan (Likert Scale 5). Pemilihan skala interval 1-5 ini digunakan untuk memudahkan responden memilih jawabannya. Skala interval sendiri adlaah skala yang memiliki nilai yang sama merepresentasikan jarak yang sama pada masingmasing skala. Penjelasan mengenai setiap skalanya adalah sebagai berikut:

$1=$ Sangat Tidak Setuju

2 = Tidak Setuju

$3=$ Netral

$4=$ Setuju

5 = Sangat Setuju

Wawancara pada penelitian kuantitatif dapat dilakukan dengan cara tidak berstruktur. Data yang didapatkan dari wawancara adalah kumpulan data verbal yang didapatkan dari percakapan atau tanya jawab dari narasumber. Peneliti memastikan bahwa narasumber atau orang yang tidak merasa keberatan jika wawancara itu direkam yang berarti selama wawancara dilaksanakan, peneliti harus menjaga etika. Penilitian ini akan mengarah kepada wawancara terhadap Wakil Direktur Utama PT Bank Syariah Indonesia. Selain wakil direktur utama peneliti juga akan meneliti 
beberapa pihak bank seperti kepala cabang, customer service officer, personal bank officer, dan juga pemimpin divisi yang bersangkutan. Tidak hanya pihak bank yang akan diteliti, nasabah yang datang ke bank juga akan diwawancarai peneliti guna memenuhi penulisan dan penelitian ini.

Pengamatan atau observasi dilakukan dengan Teknik mengamati ucapan dari seseorang dan gestur badan serta gerak-gerik badan, tangan, dan mimik atau raut wajah. Peneliti harus bisa mengamati secara seksama dan cermat serta mamknainya selama melakukan pengamatan sambil mewawancarai informan. Melalui Teknik ini, peneliti akan ikut serta dalam kegiatan ke empat cabang PT Bank Syariah Indonesia Tbk yang dikunjungi selama 5 hari guna dapat memahami secara mendalam proses program digital banking yang dimana adalah BSI Mobile dan sekaligus merasakan kelebihan jika peneliti terlibat sebagai nasabah.

Analisis Dokumen dilakukan dengan melihat dokumen pribadi dan dokumen resmi. Dokumen pribadi yang digunakan oleh peneliti untuk mencatat segala kegiatan selama melakukan pengamatan serta semua data yang sewaktu waktu dapat digunakan untuk memenuhi penulisan ini. Dokumen resmi, berupa data data yang dikumpulkan dengan cara memfotokopi ataupun arsip-arsip yang didapat dari kepustakanan maupun dengan cara mengunduh dari situs dan segala informasi data yang diberikan oleh informan akan dijadikan sebagai subyek penelitian.

8. Metode analisis data

Dalam penelitian ini akan digunakan software smartPLS untuk mengelola data. Structural Equation Modeling (SEM) adalah cara yang dipakai untuk menutupi kekurangan dari metode regresi. Metode penelitian SEM dibagi terhadap dua pendekatan, yaitu metode SEM berbasis kovarian (CBSEM) dan metode SEM berbasis varians atau metode kuadrat terkecil parsial (PLS). PLS adalah metode analisis yang kuat yang tidak berdasarkan terhadap banyak asumsi dalam metode ini. Pendekatan PLS bebas distribusi dan dapat berupa angka, kategori, urutan, interval maupun faktor. PLS memakai metode bootstrap dimana yang berarti perkalian acak dan asumsi normalitas tidak akan masalah untuk PLS. Selain itu, PLS tidak ada jumlah sampel minimal yang digunakan dalam penelitian, PLS tetap dapat digunakan walauapun penelitian yang memiliki sampel yang sedikit.

9. Pengujian Instrument Penelitian

Pada penelitian ini, metode yang digunakan untuk merubah data kualitatif menjadi kuantitatif digunakan skala likert. Menurut (Sugiyono, 2017), skala likert dapat dimanfaatkan dan digunakan dalam melakukan pengukuran terhadap sikap, pendapat dan pendapat (persepsi) seseorang atau sekolompok orang terhadap suatu fenomena sosial. Dalam instrument penelitian telah disediakan alternatif jawaban yang dimana jawaban tersebut memiliki skor / nilai.

Setelah semua jawaban terkumpul, selanjutnya akan dianalisis melalui analisis data teknis, yaitu melalui serangkaian kegiatan untuk mengelola data yang diperoleh dari hasil penelitian, kemudian membentuk sekumpulan hasil. Dua teknik dapat digunakan untuk menguji analisis data agar lebih menyeluruh dan akurat. 
a. Uji Validitas

Menurut (Sugiarto, 2017) diartikan sebagai kemampuan mengukur apa yang seharusnya diukur. Semakin tinggi keakuratan antara data yang terjadi pada objek penelitian dengan data yang dilakukan oleh peneliti artinya validitas datanya semakin tinggi. Uji validitas dilakukan dengan melihat hasil AVE (average variance extracted) yang diekstraksi pada aplikasi SmartPLS, jika lebih besar dari 0,5 maka tes tersebut dikatakan valid.

b. Uji Reliabilitas

Menurut (Sugiarto, 2017) reliabilitas berarti konsistensi, akurasi dan ketelitian. Dalam penelitian, reliabilitas berkaitan dengan konsistensi data, stabilitas, dan / atau derajat penemuan. Dalam SEM-PLS, uji reliabilitas ini dapat diukur dengan composite reliability, dimana jika hasil uji masing-masing variabel lebih besar dari 0,7 hal ini menunjukkan bahwa data reliabel; dan jika hasil uji kurang dari 0,7 menunjukkan bahwa data tidak tidak reliabel.

\section{Hasil dan Pembahasan}

1. Analisis Data Penelitian

Analisa data penelitian ini dilakukan berdasarkan penyebaran kuesioner yang dilakukan terdahap 211 responden, dimana jumlah pengembalian yang diterima adalah sebanyak 191 kuesioner. Kuesioner terdiri dari 17 pertanyaan yang akan dianalisa. Data yang terkumpul dari 191 kuesioner ini dianalisa menggunakan aplikasi smartPLS. Analisa ini terdiri dari 2 tahap yaitu outer model dengan melakukan uji validitas dan uji reliabilitas kemudian inner model untuk menguji hipotesis hubungan antar variabel laten dengan mengacu pada R-square.

2. Outer Model

Uji validitas dilakukan untuk mengetahui apakah pertanyaan yang ada pada kuesioner dapat dijadikan indikator pada variabel penelitain ini. Uji validitas ini dilakukan dengan cara melihat hasil AVE (average variance extracted), dimana batas minimum tingkat validitasnya adalah 5, dan juga nilai outer loadings. Hasil AVE dan outer loadings pada kuesioner itu sendiri adalah sebagai berikut:

Tabel 7

Hasil Uji Convergent Validity

\begin{tabular}{llll}
\hline Variabel & Indikator & \multicolumn{2}{c}{ Convergent Validity } \\
\cline { 2 - 3 } & & Outer loadings & AVE \\
\hline \multirow{4}{*}{ Kualitas Pelayanan } & SQ1 & 0,933 & \multirow{2}{*}{0,808} \\
& SQ2 & 0,896 & \\
\cline { 2 - 3 } & SQ3 & 0,915 & \multirow{2}{*}{0,662} \\
\cline { 2 - 3 } Ekuitas Merek & SQ4 & 0,848 & \\
\cline { 2 - 3 } & SQ5 & 0,900 & 0,706 \\
\hline & BE1 & 0,746 \\
\cline { 2 - 3 } & BE2 & 0,854 & 0,870 \\
\hline
\end{tabular}




\begin{tabular}{|c|c|c|c|}
\hline \multirow[t]{2}{*}{ Citra Perusahaan } & $\mathrm{BI} 2$ & 0,853 & \multirow{5}{*}{0,865} \\
\hline & BI3 & 0,848 & \\
\hline \multirow{3}{*}{ Kepuasan Pelanggan } & CS1 & 0,896 & \\
\hline & $\mathrm{CS} 2$ & 0,943 & \\
\hline & $\mathrm{CS} 3$ & 0,950 & \\
\hline \multirow{3}{*}{ Loyalitas Pelanggan } & CL1 & 0,906 & \multirow[t]{3}{*}{0,810} \\
\hline & CL2 & 0,870 & \\
\hline & $\mathrm{Cl} 3$ & 0,923 & \\
\hline
\end{tabular}

Sumber: Hasil pengolahan data

Pada tabel 7 dapat dilihat bahwa seluruh variabel yang ada memperoleh nilai diatas 0,5 , sehingga dapat dikatakan valid. Variabel Kepuasan Nasabah memiliki nilai AVE tertinggi dengan nilai 0,865, diikuti dengan variabel Loyalitas Nasabah dengan nilai 0,810, variabel Kualitas Pelayanan dengan nilai 0,808, variabel Citra Perusahaan dengan nilai 0,746, dan terkahir variabel Ekuitas Merek dengan nilai AVE terendah yaitu 0,662 . Selanjutnya hasil pengujian dilakukan melalui outer loadings. Nilai outer loadings yang semakin tinggi menandakan suatu pertanyaan semakin baik mewakili variabelnya. Hasil uji outer loadings adalah sebagai berikut:

Pada tabel 4.12 terlihat bahwa terdapat 5 variabel yang terdiri dari jumlah indikator yang berbeda dan hasil outer loadings yang juga berbeda. Variabel Kualitas Pelayanan terdiri dari 5 indikator, dimana nilai indikator tertinggi adalah SQ1 dengan nilai 0,933. SQ1 adalah pernyataan yang mengungkapkan bahwa BSI Mobile memiliki fasilitas dan fitur yang menarik. Setelah itu diikuti dengan SQ2 dengan nilai 0,896, SQ3 dengan nilai 0,915, SQ4 dengan nilai 0,848, dan SQ5 dengan nilai 0,900, dimana nilai terendah adalah SQ4. SQ4 adalah pernyataan bahwa transaksi yang dilakukan melalui BSI Mobile dapat dipercaya karena dijamin kerahasiaan dan keamanannya.

Variabel selanjutnya adalah Ekuitas Merek yang terdiri dari 3 indikator, dimana nilai indikator tertinggi adalah BE3 yaitu 0,870 yang dimana adalah pernyataan perihal fitur BSI Mobile yang lebih baik dari aplikasi bank yang digunakan sebelumnya. Selanjutnya BE1 dengan nilai 0,706 dan BE2 dengan nilai 0,854 . Indikator dengan nilai paling rendah adala BE 1 dengan nilai 0,706 yang dimana menanyakan perihal pelanggan yang hanya menggunakan aplikasi BSI Mobile saja untuk transaksi perbankan.

Variabel selanjutnya adalah Citra Perusahaan yang terdiri dari 3 indikator, dimana nilai indikator tertinggi adalah BI1 dengan nilai 0,891 yang menyatakan perihal kemudahan dalam penggunaan BSI mobile, selanjutnya diikuti dengan BI2 dengan nilai 0,853 dan BI3 dengan nilai terendah yaitu 0,848 dimana menjelaskan mengenai BSI Mobile yang merupakan aplikasi perbankan Syariah yang terpercaya.

Variabel berikutnya adalah Kepuasan Pelanggan yang juga terdiri dari 3 indikator, dimana nilai indikator tertinggi adalah CS3 dengan nilai 0,950 yang menanyakan mengenai secara keseluruhan kepuasan pelanggan terhadap fitur 
layanan BSI Mobile. Diikuti dengan indikator CS1 dengan nilai 0,896 dan yang terendah adalah $\mathrm{C} 2$ dengan nilai 0,943 .

Variabel terakhir adalah variabel Loyalitas Pelanggan, dimana nilai indikator tertinggi adalah pada indikator CL3 dengan nilai 0,923 tentang menyarankan nasabah lain untuk menggunakan BSI Mobile dengan berbagai keuntungan yang didapatkan, diikuti dengan CL1 dengan nilai 0,906 dan CL2 dengan nilai 0,870.

Setelah melakukan uji validitas maka dilakukan uji korelasi antar variabel yang dilakukan melalui uji Fornell Lacker discriminant validity. Hasil uji tersebut dapat dilihat dari nilai $\sqrt{ }$ AVE setiap variabel yang terdapat pada tabel berikut ditandai dengan bold, dimana nilai $\sqrt{ }$ AVE tersebut harus lebih tinggi dari nilai korelasi antar variabel. Hasil uji selengkapnya akan dijabarkan sebagai pada tabel 8 .

\section{Tabel 8}

Hasil Uji Fornell Larcker Discriminant Validity

\begin{tabular}{llllll}
\hline & $\begin{array}{l}\text { Kualitas } \\
\text { Pelayanan }\end{array}$ & $\begin{array}{l}\text { Ekuitas } \\
\text { Merek }\end{array}$ & $\begin{array}{l}\text { Citra } \\
\text { Perusahaan }\end{array}$ & $\begin{array}{l}\text { Kepuasan } \\
\text { Pelanggan }\end{array}$ & $\begin{array}{l}\text { Loyalitas } \\
\text { Pelanggan }\end{array}$ \\
\hline Kualitas Pelayanan & 0,899 & & & & \\
\hline Ekuitas Merek & 0,762 & 0,814 & & & \\
\hline Citra Perusahaan & 0,830 & 0,681 & 0,864 & & 0,900 \\
\hline Kepuasan Pelanggan & 0,860 & 0,760 & 0,828 & 0,930 & 0,837 \\
\hline Loyalitas Pelanggan & 0,810 & 0,756 & 0,789 & & 0 \\
\hline
\end{tabular}

Sumber: Hasil pengolahan data

Berdasarkan tabel diatas $\sqrt{ }$ AVE variabel Kualitas Pelayanan adalah 0,899 atau merupakan nilai variabel paling tinggi diantara variabel lainnya.

$\sqrt{ }$ AVE variabel Ekuitas Merek adalah 0,814 dimana nilai korelasi antara variabel Ekuitas Merek dengan Kualitas Pelayanan adalah 0.,762 atau lebih kecil dari $\sqrt{ }$ AVE variabel Ekuitas Merek.

$\sqrt{ }$ AVE variabel Citra Perusahaan adalah 0,864 dimana nilai korelasi antara variabel Citra Perusahaan dengan variabel Kualitas Pelayanan adalah 0,830 dan nilai korelasi dengan variabel Ekuitas Merek adalah 0,681 atau lebih kecil dari $\sqrt{ }$ AVE variabel Citra Perushaaan.

$\sqrt{ }$ AVE variabel Kepuasan Pelanggan adalah 0,930 dimana nilai korelasi antara variabel Kepuasan Pelanggan dengan Kualitas Pelayanan adalah 0,860, nilai korelasi antara variabel Ekuitas Merek adalah 0,760 dan nilai korelasi antara variabel Citra

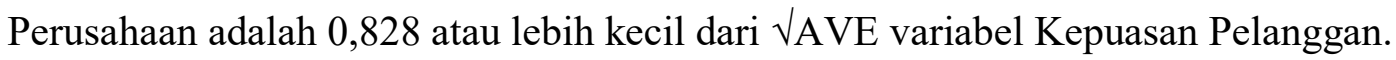

$\sqrt{ }$ AVE variabel Loyalitas Pelanggan adalah 0,900 dimana nilai korelasi antara variabel Loyalitas Pelanggan dengan variabel Kualitas Pelayanan adalah 0,810, nilai korelasi antara variabel Ekuitas Merek adalah 0,756, nilai korelasi antara variabel Citra Perusahaan adalah 0,789, nilai korelasi antara variabel Kepuasan Pelanggan adalah 0,837 atau lebih kecil dari $\sqrt{ }$ AVE variabel Loyalitas Pelanggan.

Uji Reliabilitas dilakukan dengan melakukan perhitungan Composite Reliablity pada aplikasi SEM-PLS dengan ketentuan bahwa setiap variabel yang diuji harus memiliki hasil lebih besar dari 0,7 untuk menunjukan bahwa data ini reliable. Hasil 
uji ini sendiri seluruhnya memiliki nilai diatas 0,7 yang menunjukan data yang diperoleh dari penyebaran kuesioner ini adalah reliable dengan hasil ditunjukan pada tabel 9.

Tabel 9

Hasil Uji Composite Reliability

\begin{tabular}{ll}
\hline Variabel & Composite Reliability \\
\hline Kualitas Pelayanan & 0,955 \\
\hline Ekuitas Merek & 0,854 \\
\hline Citra Perusahaan & 0,898 \\
\hline Kepuasan Pelanggan & 0,950 \\
\hline Loyalitas Pelanggan & 0,927 \\
\hline
\end{tabular}

Sumber: Hasil pengolahan data

Hasil uji reliabilitas pada penelitian ini menunjukan hasil yang diperoleh untuk keseluruhan variabel lebih dari 0,7 dimana nilai composite reliability tertinggi adalah variabel Kualitas Pelayanan yaitu 0,955, nilai variabel Ekuitas Merek adalah 0,854, nilai variabel Citra Perusahaan adalah 0,898, nilai variabel Kepuasan Pelanggan adalah 0,950 dan nilai variabel Loyalitas Pelanggan adalah 0,927.

3. Inner Model

Pengukuran inner model dilakukan berdasarkan perhitungan nilai R-square yang merupakan goodness of fit. Menurut (Latan, Noonan, \& Matthews, 2017) pengujian berdasarkan inner model ini akan menunjukan hubungan antara variabelvariabel laten berdasarkan teori penelitian. Penggolongan R-Square pada tingkatan 0,25, 0,5 dan 0,75 yang dapat disimpulkan suatu model lemah, moderat dan kuat. Pada penelitian ini hasil R-Square dijelaskan pada tabel 10.

Tabel 10

Hasil Uji R-Square

\begin{tabular}{ll}
\hline Variabel & R Square \\
\hline Ekuitas Merek & 0,581 \\
\hline Citra Perusahaan & 0,695 \\
\hline Kepuasan Pelanggan & 0,800 \\
\hline Loyalitas Pelanggan & 0,761 \\
\hline
\end{tabular}

Sumber: Hasil pengolahan data

Berdasarkan hasil nilai yang diperoleh, R-Square variabel Ekuitas Merek adalah sebesar 0,581 atau dapat dijelaskan bahwa 58,1\% Ekuitas Merek dapat dijelaskan oleh perubahan pada variabel Kualitas Pelayanan. Sementara Sisanya yaitu 41,9\% disebabkan faktor lainnya yang tidak tergambarkan pada model. Sementara R-Square variabel Citra Perusahaan adalah sebesar 0,695 atau dapat dijelaskan bahwa 69,5\% Citra Perusahhaan dapat dijelaskan oleh perubahan variabel Kualitas Pelayanan dan Ekuitas Merek. Sementara sisanya yaitu 30,5\% disebabkan faktor lainnya yang tidak tergambarkan pada model. Selanjutnya R-Square variabel Kepuasan Nasabah adalah sebesar 0,800 atau dapat dijelaskan bahwa 80\% Kepuasan 
Nasabah dapat dijelaskan oleh perusbahan pada variabel Kualitas Pelayanan, Ekuitas Merek, dan Citra Perusahaan. Sementara sisanya yaitu 20\% disebabkan faktor lainnya yang tidak tergambarkan pada model. Terakhir adalah variabel Loyalitas Pelanggan, R-Square variabel Loyalitas Pelanggan adalah sebesar 0,761 atau dapat dijelaskan bahwa 76,1\% Loyalitas Pelanggan dapat dijelaskan oleh perubahan variabel Kualitas Pelayanan, Ekuitas Merek, Citra Perusahaan, dan Kepuasan Pelanggan. Sementara sisanya yaitu $23,9 \%$ disebabkan faktor lainnya yang tidak tergambarkan pada model.

4. Pembahasan

Setelah melakukan outer model melalui uji validitas dan reliabilitas, serta melakukan inner model melalui R-square, tahap selanjutnya adalah menguji apakah variabel independen secara parsial berpengaruh signifikan terhadap variabel dependen pada penelitian ini, Pengujian dilakukan dengan mengacu kepada P-Value. Penelitian ini termasuk pada penelitian two-tailed dengan tingkat kepercayaan sebesar $95 \%$ sehingga $\mathrm{P}$-value yang terlihat pada path coefficient adalah sebesar 0,05 dimana signifikansi dapat disimpulkan apabila nilai P-value lebih rendah atau sama dengan 0,05. Hasil pengujian hipotesis dan gambar model struktural dengan path coefficient dan P-Value dijelaskan pada tabel 11.

\section{Tabel 11}

Uji Hipotesis

\begin{tabular}{llll}
\hline & $\begin{array}{l}\text { Standardized } \\
\text { Coefficient Path }\end{array}$ & $\begin{array}{l}\text { P } \\
\text { Value }\end{array}$ & Kesimpulan \\
\hline $\begin{array}{l}\text { H1 Kualitas Pelayanan terhadap } \\
\text { Ekuitas Merek }\end{array}$ & 0,762 & 0,000 & Didukung \\
\hline $\begin{array}{l}\text { H2 Kualitas Pelayanan terhadap Citra } \\
\text { Perusahaan }\end{array}$ & 0,742 & 0,000 & Didukung \\
\hline $\begin{array}{l}\text { H3 Pelayanan terhadap Kepuasan } \\
\text { Pelanggan }\end{array}$ & 0,424 & 0,000 & Didukung \\
\hline $\begin{array}{l}\text { H4 Kualitas Pelayanan terhadap } \\
\text { Loyalitas Pelanggan }\end{array}$ & 0,160 & 0,081 & Tidak \\
\hline $\begin{array}{l}\text { H5 Ekuitas Merek terhadap Citra } \\
\begin{array}{l}\text { Perusahaan } \\
\text { H6 Ekuitas Merek terhadap Kepuasan }\end{array}\end{array}$ & 0,116 & 0,105 & $\begin{array}{l}\text { Tidak } \\
\text { Pelanggan }\end{array}$ \\
$\begin{array}{l}\text { H7 Ekuitas Merek terhadap Loyalitas } \\
\text { Pelanggan }\end{array}$ & 0,218 & 0,000 & Dikukung \\
\hline $\begin{array}{l}\text { H8 Citra Perusahaan terhadap } \\
\text { Kepuasan Pelanggan }\end{array}$ & 0,333 & 0,007 & Didukung \\
\hline $\begin{array}{l}\text { H9 Citra Perusahaan terhadap } \\
\text { Loyalitas Pelanggan }\end{array}$ & 0,208 & 0,000 & Didukung \\
\hline $\begin{array}{l}\text { H10 Kepuasan Pelanggan terhadap } \\
\text { Loyalitas Pelanggan }\end{array}$ & 0,362 & 0,011 & Didukung \\
\hline
\end{tabular}

Sumber: Hasil pengolahan data 


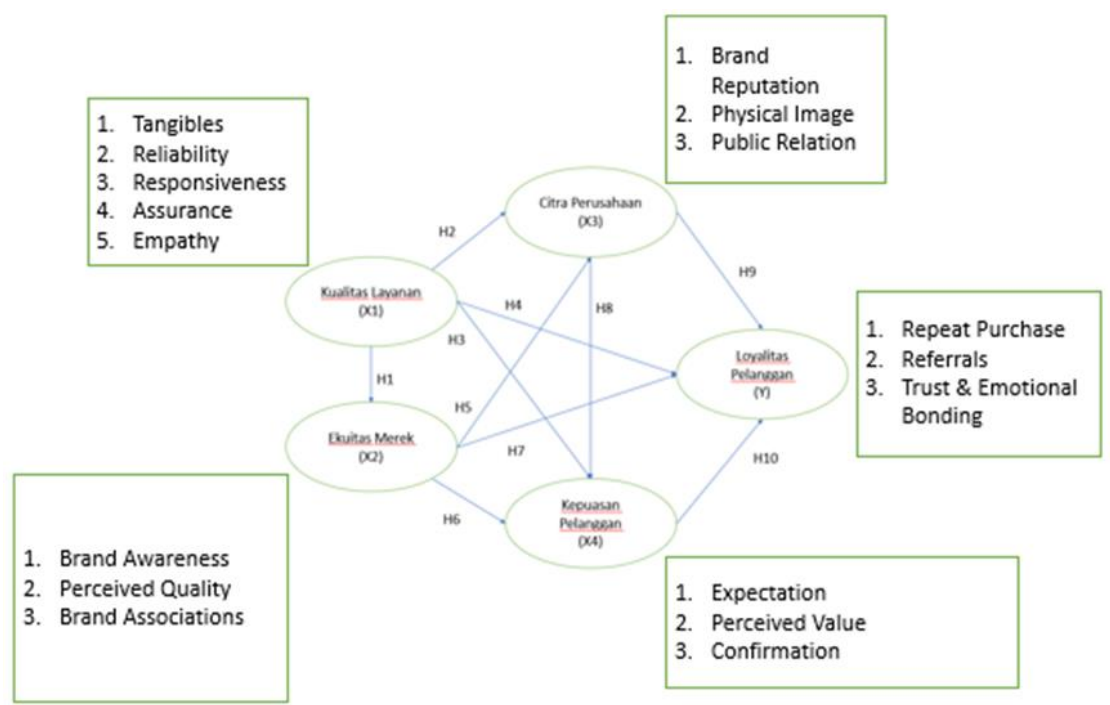

\section{Gambar 1 \\ Model Struktural \\ Sumber: Hasil pengolahan data}

Berdasarkan gambar diatas dapat dilihat bahwa terdapat 10 hipotesis. Hipotesis pertama adalah "Terdapat pengaruh variabel Kualitas Pelayanan terhadap variabel Ekuitas Merek“ dimana nilai standardized coefficient path pada hipotesis ini adalah 0,762 dan nilai $\mathrm{P}$ value 0,000 atau lebih rendah dari parameter $\mathrm{P}$ value 0,05 sehingga dapat disimpulkan terdapat pengaruh signifikan variabel Kualitas Pelayanan terhadap variabel Ekuitas Merek.

Hipotesis ke-dua adalah "Terdapat pengaruh variabel Kualitas Pelayanan terhadap variabel Citra Perusahaan" dimana nilai standardized coefficient path pada hipotesis ini adalah 0.742 dan nilai $\mathrm{P}$ value 0.000 atau lebih rendah dari parameter $\mathrm{P}$ value 0.05 sehingga dapat disimpulkan terdapat pengaruh signifikan variabel Kualitas Pelayanan terhadap variabel Citra Perusahaan.

Hipotesis ke-tiga adalah "Terdapat pengaruh variabel Kualitas Pelayanan terhadap variabel Kepuasan Pelanggan" dimana nilai standardized coefficient path pada hipotesis ini adalah 0.424 dan nilai $\mathrm{P}$ value 0.000 atau lebih rendah dari parameter $\mathrm{P}$ value 0.05 sehingga dapat disimpulkan terdapat pengaruh signifikan variabel Kualitas Pelayanan terhadap variabel Kepuasan Pelanggan.

Hipotesis ke-empat adalah "Terdapat pengaruh variabel Kualitas Pelayanan terhadap variabel Loyalitas Pelanggan" dimana nilai standardized coefficient path pada hipotesis ini adalah 0.160 dan nilai $\mathrm{P}$ value 0.081 atau lebih tinggi dari parameter $\mathrm{P}$ value 0.05 sehingga dapat disimpulkan tidak terdapat pengaruh signifikan variabel Kualitas Pelayanan terhadap variabel Loyalitas Pelanggan. Hasil sesuai dengan penilitian yang dilakukan oleh (Napitupulu \& Lukiyana, 2017) dimana hasil dilakukan di PT Taksi Blue Bird Group Jakarta menunjukan bahwa Kualitas Pelayanan tidak berpengaruh signifikan terhadap Loyalitas Nasabah. Hal ini dikuatkan dengan wawancara yang dilakukan kepada Wakil Direktur Utama PT Bank Syariah Indonesia Abdullah Firman Wibowo, didapatkan informasi bahwa peristiwa ini dapat disebabkan 
oleh proses migrasi sistem bank legacy menjadi sistem baru yaitu sistem Bank Syariah Indonesia yang masih baru dan belum sepenuhnya terlaksana setelah merger dilakukan. Dalam hal ini dikarenakan sistem BSI Mobile yang masih baru dan masih banyak memiliki kekurangan, serta dibutuhkan waktu untuk membiasakan pengguna untuk menggunakan aplikasi baru yaitu BSI Mobile dan meninggalkan aplikasi perbankan dari bank legacy, maka kualitas pelayanan BSI Mobile tidak mempengaruhi loyalitas pelanggan secara signifikan pada saat ini dikarenakan pelanggan diharuskan untuk melakukan migrasi secara sukarela (voluntarily) atau secara automigrasi.

Hipotesis ke-lima adalah "Terdapat pengaruh variabel Ekuitas Merek terhadap variabel Citra Perusahaan" dimana nilai standardized coefficient path pada hipotesis ini adalah 0.116 dan nilai $\mathrm{P}$ value 0.105 atau lebih tinggi dari parameter $\mathrm{P}$ value 0.05 sehingga dapat disimpulkan tidak terdapat pengaruh signifikan variabel Ekuitas Merek terhadap variabel Citra Perusahaan. Tidak ditemukan rujukan yang mendukung hasil ini, tetapi berdasarkan wawancara yang dilakukan kepada Wakil Direktur Utama PT Bank Syariah Indonesia Abdullah Firman Wibowo, didapatkan informasi bahwa pada saat setelah merger, PT Bank Syariah Indonesia belum memiliki Ekuitas Merek yang tinggi di karenakan masih harus banyak dilakukan sosialisasi secara internal maupun kepada masyarakat luar mengenai keberadaan Bank Syariah Indonesia ini. Namun pada saat ini fokus utama dari PT Bank Syariah Indonesia Tbk adalah untuk melakukan integrasi sistem internal seperti: penyesuaian budaya kerja, penyesuaian teknologi (roll-out) dan integrasi jaringan. Dalam hal ini dapat disampaikan bahwa pada saat Ekuitas Merek milik PT Bank Syariah Indonesia dan juga BSI Mobile tidak mempengaruhi Citra Perusahaan PT Bank Syariah Indonesia yang masih melekat pada Citra Perusahaan bank legacy.

Hipotesis keenam adalah "Terdapat pengaruh variabel Ekuitas Merek terhadap variabel Kepuasan Pelanggan" dimana nilai standardized coefficient path pada hipotesis ini adalah 0.210 dan nilai $\mathrm{P}$ value 0.000 atau lebih rendah dari parameter $\mathrm{P}$ value 0.05 sehingga dapat disimpulkan terdapat pengaruh signifikan variabel Ekuitas Merek terhadap variabel Kepuasan Pelanggan.

Hipotesis ke-tujuh adalah "Terdapat pengaruh variabel Ekuitas Merek terhadap variabel Loyalitas Pelanggan" dimana nilai standardized coefficient path pada hipotesis ini adalah 0.218 dan nilai $P$ value 0.007 atau lebih rendah dari parameter $P$ value 0.05 sehingga dapat disimpulkan terdapat pengaruh signifikan variabel Ekuitas Merek terhadap variabel Loyalitas Pelanggan.

Hipotesis ke-delapan adalah "Terdapat pengaruh variabel Citra Perusahaan terhadap variabel Kepuasan Pelanggan" dimana nilai standardized coefficient path pada hipotesis ini adalah 0.333 dan nilai $\mathrm{P}$ value 0.000 atau lebih rendah dari parameter $\mathrm{P}$ value 0.05 sehingga dapat disimpulkan terdapat pengaruh signifikan variabel Citra Perusahaan terhadap variabel Kepuasan Pelanggan.

Hipotesis ke-sembilan adalah "Terdapat pengaruh variabel Citra Perusahaan terhadap variabel Loyalitas Pelanggan" dimana nilai standardized coefficient path pada hipotesis ini adalah 0.208 dan nilai $\mathrm{P}$ value 0.011 atau lebih rendah dari parameter $\mathrm{P}$ 
value 0.05 sehingga dapat disimpulkan terdapat pengaruh signifikan variabel Citra Perusahaan terhadap variabel Loyalitas Pelanggan.

Hipotesis ke-sepuluh adalah "Terdapat pengaruh variabel Kepuasan Pelanggan terhadap variabel Loyalitas Pelanggan" dimana nilai standardized coefficient path pada hipotesis ini adalah 0.362 dan nilai $\mathrm{P}$ value 0.001 atau lebih rendah dari parameter $\mathrm{P}$ value 0.05 sehingga dapat disimpulkan terdapat pengaruh signifikan variabel Kepuasan Pelanggan terhadap variabel Loyalitas Pelanggan.

\section{Kesimpulan}

Penelitian ini dilakukan untuk melihat pengaruh Kepuasan Nasabah, Ekuitas Merek, Citra Perusahaan, dan Kepuasan Pelanggan terhadap Loyalitas Pelanggan pada BSI Mobile milik PT Bank Syariah Indonesia Tbk. Berdasarkan penelitian yang dilakukan, maka dapat diambil kesimpulan dimana: a). Kualitas Pelayanan memiliki pengaruh yang positif dan signifikan terhadap Ekuitas Merek pada BSI Mobile. b). Kualitas Pelayanan memiliki pengaruh yang positif dan signifikan terhadap Citra Perusahaan pada BSI Mobile. c). Kualitas Pelayanan memiliki pengaruh yang positif dan signifikan terhadap Kepuasan Pelanggan pada BSI Mobile. d). Kualitas Pelayanan memiliki pengaruh yang positif namun tidak signifikan terhadap Loyalitas Pelanggan pada BSI Mobile. e). Ekuitas Merek memiliki pengaruh yang positif namun tidak signifikan terhadap Citra Perusahaan pada BSI Mobile. f). Ekuitas Merek memiliki pengaruh yang positif dan signifikan terhadap Kepuasan Pelanggan pada BSI Mobile. g). Ekuitas Merek memiliki pengaruh yang positif dan signifikan terhadap Loyalitas Pelanggan pada BSI Mobile. h). Citra Perusahaan memiliki pengaruh yang positif dan signifikan terhadap Kepuasan Pelanggan pada BSI Mobile. i). Citra Perusahaan memiliki pengaruh yang positif dan signifikan terhadap Loyalitas Pelanggan pada BSI Mobile. j). Kepuasan Pelanggan memiliki pengaruh yang positif dan signifikan terhadap Kepuasan Pelanggan pada BSI Mobile.

Hasil penelitian menunjukan bahwa variabel yang berpengaruh positif terhadap Loyalitas Nasabah PT Bank Syariah Indonesia dalam penggunaan BSI Mobile adalah variabel Ekuitas Merek, Citra Perusahaan, dan Kepuasan Nasabah. Hal ini berarti semakin baik keempat variabel tersebut maka semakin baik juga tingkat loyalitas nasabah. Namun, pada penelitian ini juga dibuktikan bahwa Kualitas Layanan tidak berpengaruh signifikan terhadap Loyalitas Nasabah dimana yang berarti hanya sekedar kualitas yang baik saja tidak cukup untuk membuat pelanggan yang loyal. 


\section{BIBLIOGRAFI}

Arikunto, S. (2016). Prosedur Penelitian Suatu Pendekatan Praktis. Jakarta: Bhineka Cipta. Google Scholar

Gerrard, Philip, \& Cunningham, J. Barton. (2004). Consumer switching behavior in the Asian banking market. Journal of Services Marketing. Google Scholar

Keuangan, Otoritas Jasa. (2015). Bijak Ber-eBanking. Jakarta: OJK. Google Scholar

Kotler, Philip, \& Keller, Kevin Lane. (2016). Marketing management (15th global ed.). England: Pearson.

Latan, Hengky, Noonan, Richard, \& Matthews, L. (2017). Partial least squares path modeling. Partial Least Squares Path Modeling: Basic Concepts, Methodological Issues and Applications. Https://Doi. Org/10.1007/978-3-319-64069-3 DOI: Https://Doi. Org/10.1007/978-3-319-64069, 3. Google Scholar

Limbong, Tonni, Muttaqin, Muttaqin, Iskandar, Akbar, Windarto, Agus Perdana, Simarmata, Janner, Mesran, Mesran, Sulaiman, Oris Krianto, Siregar, Dodi, Nofriansyah, Dicky, \& Napitupulu, Darmawan. (2020). Sistem Pendukung Keputusan: Metode \& Implementasi. Yayasan Kita Menulis. Google Scholar

Napitupulu, Eva, \& Lukiyana, Lukiyana. (2017). Pengaruh Kualitas Pelayanan Dan Kepercayaan Merek Terhadap Loyalitas Konsumen Dengan Kepuasan Konsumen Sebagai Variabel Intervening Pada Pt. Taksi Blue Bird Group Jakarta. Media Manajemen Jasa, 5(2). Google Scholar

Sugiarto, Eko. (2017). Menyusun proposal penelitian kualitatif: Skripsi dan tesis: Suaka media. Diandra Kreatif. Google Scholar

Sugiyono. (2017). Metode Penelitian Kuantitatif. Alfabeta: Bandung

Supranto, J., \& Limiakrisna, H. N. (2011). Perilaku Konsumen dan Strategi Pemasaran. Jakarta: Mitra Wacana Media. Google Scholar

Tjiptono, Fandy, \& Chandra, Gregorius. (2011). Service, quality \& satisfaction.

\section{Copyright holder:}

Alan Andhika (2021)

First publication right:

Syntax Literate: Jurnal Ilmiah Indonesia

This article is licensed under:

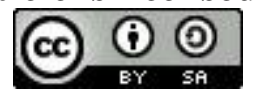

